\title{
Interaction between Teachers and Students in College English Language Teaching
}

\author{
Li Wenwen \\ School of International Education, Shandong Xiehe University, Shandong, China, 250109
}

Keywords: College English; language teaching; teacher-student interaction

\begin{abstract}
In recent years, the level of College English teaching has been greatly improved, especially the current situation of language teaching. Students have also gained more knowledge and skills from language classroom teaching. However, there are still many problems in the classroom teaching of College English language course, which seriously hinder the further improvement of College English teaching level and greatly affect the improvement of studentship ability. Enhancing the interaction between teachers and students is one of the means to improve the quality of College English language teaching. College English teachers should attach great importance to it. This paper first analyses the problems in College English language teaching, then analyses the role of teacher-student interaction in College English language teaching, and finally discusses the ways of teacher-student interaction in detail, hoping to provide some reference for future research.
\end{abstract}

English is an international language. The purpose of improving college English teaching is to improve studentship level and to provide more excellent English application-oriented talents for the society. The development of College English language teaching should be a process of communication and discussion between teachers and students. In the process of teaching, teachers should not only play the role of knowledge impairment, but also play the role of learning guide. They should regard students as the main body of learning, hand more initiative into studentships, stimulate students' interest in learning, and enhance nonadministrative and creativity. Sex. In this way, Interactive College English language teaching will greatly enhance interlanguage "output" ability, change the serious imbalance between "input and output" in the past, thus promoting the development of College English language teaching and laying the foundation for improving college students' comprehensive English ability.

\section{The Trend of Interactive Teaching in College Oral English Teaching}

In recent years, interactive approach has been more and more widely adopted by teachers in the classroom of second foreign language teaching, which aims to cultivate telecommunications competence as the guidance of classroom activities, and to adjust the focus of classroom teaching by changing the appropriate roles between teachers and students. Through the interaction between teachers and students, we can effectively avoid the boring classroom atmosphere, prevent students from getting bored, and make them have more time to contact with the real English world. Effective 
classroom communication and counteraction between teachers and students abandoned the teacher-centered teaching mode in classroom teaching, changed the teaching mode that teachers spent a lot of time teaching and students listened to the teacher's explanations, greatly improved the teaching efficiency. With the development of English language teaching theory and the continuous reform of English education system, interactive learning will play an increasingly important role in promoting comprehensive understanding of the language and improving their communicative competence.

\section{The purpose of teacher-student interaction}

In 1971, the famous American linguist Hams formally put forward the concept of communicative competence in his article on communicative competence. As an important means of social communication, Hams believes that language must have its rules of use, otherwise grammatical rules will be meaningless. Language, as the most important means of communication, requires the speaker to speak accurately, completely and orderly, so that people can understand it as soon as they understand it. The process of fluent language expression is a process of clear thought arrangement. The ultimate goal of language teaching is to cultivate demonstrability to use the language they have learned in daily life. "Use" refers to telecommunications competence. It includes not only the level of mastering language knowledge, but also the level of how to use language correctly in the process of communication. Language teaching should enable students to acquire linguistic knowledge and communicative competence at the same time.

The interactive language teaching method is inspired by the communicative approach, aiming at strengthening the cultivation and improvement of studentship ability. It makes foreign language classroom teaching not only a unilateral exchange of information, but also a way and a process of interactive learning between teachers and students and between students and students. Through the interaction between teachers and students, the classroom atmosphere can be activated, the student-centered classroom teaching can be realized, and the teaching efficiency can be improved.

\section{Problems in College English Language Teaching}

\section{The teaching mode is single and the teaching method is backward}

\section{Studentship is not correct and they lack interest in learning}

\section{Problems in Sennacherib Playing}

Figure 1. Problems in College English Language Teaching

As shown in figure 1, a detailed analysis is presented below.

\subsection{The teaching mode is single and the teaching method is backward}

For a long time, College English language teaching has been unable to break through the shackles of traditional teaching concepts, and to break through the limitations of the original teaching ideas in a short time. It is precisely because of the existence of such old teaching concepts that the existence of a single teaching mode and backward teaching methods results. In the process of English language teaching, the classroom teaching mode of teacher-centered lecture and student-centered listening is still a common problem in foreign language teaching in most colleges 
and universities. Teachers say on the platform that students write down under the platform, ask questions properly in class, assign homework to students after class, traditional, mono and full-time classroom teaching can no longer meet the requirements of educational development, nor meet the needs of developmental, violate the rules of language learning, and at the same time, it is not conducive to the cultivation of students' comprehensive English ability, or even play a certain role. Negative effects. As shown in figure 2.

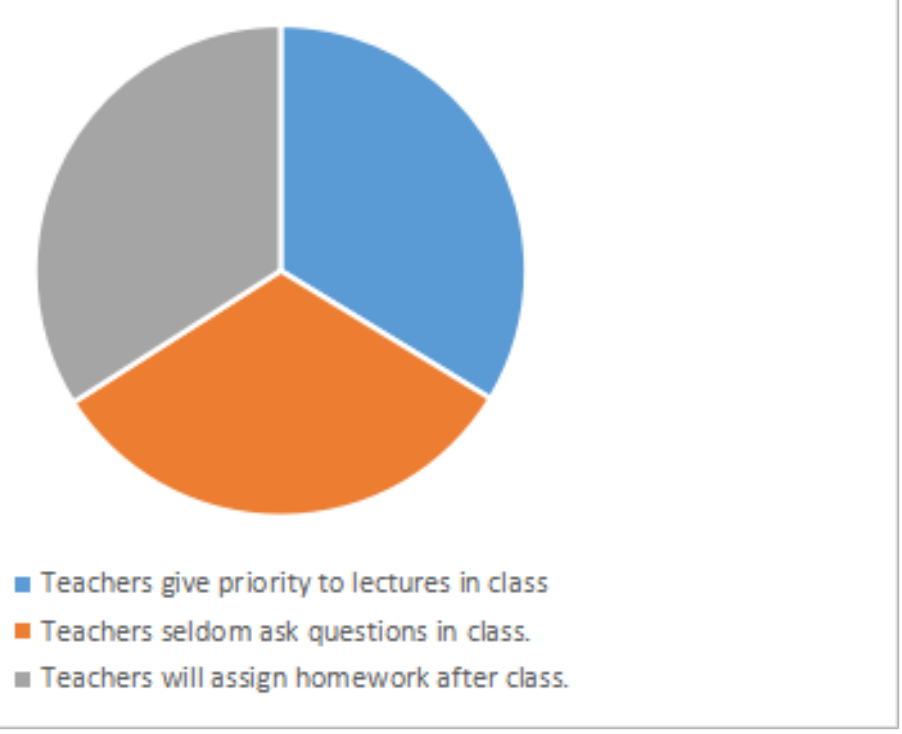

Figure 2.The teaching mode is single and the teaching method is backward

\subsection{Studentship is not correct and they lack interest in learning}

In the view of some students, the university stage is a very important stage in life. The learning effect of this stage is likely to be directly related to the future direction of life. We should seize this precious stage of life. At the same time, some students think that the university stage can relax their own requirements, there is no need to work as hard as the high school stage. For those students who have a wrong understanding of the university, in English language teaching, they have not formed a correct attitude towards learning, learning with a passable attitude, and think that their choice of English majors or learning English courses is not original intention, they have no interest in English, just to complete the learning tasks set by the school. Because students hold such a learning tower attitude, no matter how hard teachers work in the classroom, they can not achieve the desired teaching effect.

\subsection{Problems in sennacherib playing}

The most important function of language is to communicate. Language can build a bridge between people. As an international common language, English plays an extremely important role in human communication. In College English language classroom teaching, we should attach importance to the role of language communication, and strengthen communication between teachers and students. That is to say, in the process of language classroom teaching, teachers should not only play the role of knowledge impairment, but also the role of language guide, regard students as the main body of teaching, pay attention to denuclearizing feelings, and take into account students' knowledge acceptance response. However, the dullness of classroom teaching is still unchangeable. Classroom teaching according to the texts makes it difficult for students to speak. Most English teachers only use less than $10 \%$ of the time to give students practical application. The rest of the 
time is teachers'"acting alone", and students' knowledge is passively baptized by English language knowledge.

\section{Interactive College English Classroom Teaching Reform Measures and Optimizing Strategies}

\subsection{Establish the concept of interaction and create an interactive atmosphere}

Establishing a clear concept of interaction is an important means to do a good job of classroom interaction activities and cultivate telecommunications competence. Teachers should also keep pace with the times in ideology, change the traditional teaching concept of teacher-centered teaching, and clearly recognize that the first task of teaching is to cultivate telecommunications competence. Teachers should publicize the concept of classroom interaction in order to make students understand the learning objectives. English learning should not be limited to the teaching of grammar and vocabulary knowledge, but should focus on the cultivation of communicative competence. Teachers should cultivate studentship of interaction, enable students to actively participate in classroom interaction activities, make the classroom atmosphere become positive, encourage students to express themselves, create a good interactive atmosphere, and achieve the purpose of English learning.

\subsection{Enriching the form of interaction and improving the efficiency of interaction}

Diversified forms of classroom interaction can stimulate uninteresting in learning, enable students to actively participate in classroom interaction, and promote language output ability. Teachers should organize diversified forms of interaction, so that the classroom has been in a warm atmosphere. Diversified ways of interaction between teachers and students can make students have more ways of language input and output. It not only provides students with opportunities for language output, but also facilitates the communication between students and improves uninteresting and enthusiasm in learning. If only a single interactive way is used, students will feel monotonous and unable to actively learn. Therefore, the measure of Interactive College English classroom teaching reform is to develop more interactive means and apply various forms of interaction to cultivate and improve telecommunications competence.

\subsection{Strengthening interactive supervision and optimizing interactive feedback}

College English is usually taught in large classes, while interactive activities are a student-centered, teacher-guided teaching model, which is prone to some unpredictable factors, which teachers may not have been able to predict before. For these temporary situations, teachers should take good measures to deal with them before class. In addition, we often require students to interact in groups. For group activities, teachers as organizers must organize group leaders and Deputy Group leaders, implement group Responsibility system, let them supervise the members of each group, let students know that only when they cooperate well with the members, can they accomplish their tasks. Teachers should give timely feedback during or after student interaction, which should be positive feedback rather than pure error correction feedback. Headteacher should, on the one hand, give students appropriate help so that they can smoothly overcome communication barriers and increase language output. On the other hand, it should relieve students' pressure and let them put down their burdens and continue with their thinking. 


\section{Conclusion}

At present, an interactive teaching model has been established in College English teaching. It is of great significance to cultivate uninteresting in learning, stimulate students' self-confidence and improve teaching efficiency. Although there are some problems that need to be solved urgently in the process of teaching, as long as the corresponding measures are put forward, the classroom teaching model can be optimized and the students can be encouraged to be active. Learn, and improve communication skills, lay a solid foundation for future development.

\section{References}

[1] Chen Hipping, Chi Milling, Deng Guangzhou. Study on the Interaction of Learning Games in College English Vocabulary Acquisition [J]. Modern Educational Technology, 2012, (9): 61-64.

[2] Bhang Xiang. Application of Visual Interaction Based on Concept Map in English Reading Teaching [J]. China Audiovisual Education, 2013, (3): 106-110.

[3] Bhang Xiang. Schema Interactive Visualization in English Reading Teaching [J]. China Audiovisual Education, 2014, (3): 123-128.

[4] Ge An. On the Difficulties and Countermeasures of Interactive Multimedia Teaching Applied in College English Classroom [J]. Michelangelo Social Sciences, 2012, (3): 135-137.

[5] Wang Li. On Teacher-Student Interaction in College English Language Teaching Classroom [J]. Journal of Chengdu Teachers College for Nationalities, 2006, (04): 102-104. 